\section{Revelando o Brasil em Marighella: entre a recepção cinematográfica e a perspectiva bakhtiniana}

Revealing Brazil in Marighella: between the cinematographic reception and Bakhtin's approaches

Guilherme de Moura CUNHA (UFG) houveraguilherme@gmail.com

Recebido em: 27 de ago. de 2020. Aceito em: 06 de out. de 2020.

. 
V. 11 (1)

1-19

jan-abr

2021

Abstract: This paper analyzes, through a diachronic view about the formation of brazilian cinema, reactions in reply to production of Marighella (2019), film directed by Wagner Moura. From a clipping of the reader-response criticism proposed by Metz (1977) in semiology of the cinema, I intend to argue how the brazilian film is seen about to be released, according ideological aspects who creates the social representation and the cinematographic critics. Therefore, I follow a relation with the ideas of verbal interaction and dialogism, theorized by Bakhtin (2002; 2003; 2013a; 2013b) and Bakhtin/Volóchinov (2014), the definition of semiotic-ideological unity as expression of human language. Then, I realize a research in brazilian social network Filmow, where films can be rated and reviewed, to analyze the content of the published comments. Based on a qualitative observation of twenty posts, I find an effervescent discussion about the representation of the main character and the metacritics, critics about critics.

Keywords: Brazilian cinema. Bakhtin's theory. Marighella.

\section{Introdução}

Após uma série de debates em torno da democratização do acesso ao cinema no campo da crítica, mobilizados a partir de um desejo de ampliação e visibilidade da produção nacional, este artigo procura investigar as raízes do obstáculo dessa expansão e, principalmente, suas mobilizações concretas na/pela linguagem. A princípio, definese o que é cinema de acordo com a teoria cinematográfica de linha francesa, de ordenação pós-estruturalista, com centro nos estudos de Metz (1977), os quais consideram o cinema como sistema semiótico revestido de conteúdos semânticos; em seguida, evoca-se a teoria sígnica de Bakhtin (2002; 2003; 2013a; 2013b) e Bakhtin/Volóchinov (2014) para compreender como fatores ideológicos direcionam a enunciação, refletindo e refratando a realidade natural e social dos sujeitos históricos, incluindo a realidade cinematográfica. Com esse plano, parte-se para a análise do corpus selecionado - vinte comentários publicados na página "Marighella" na rede Filmow -, segundo três tipos de avaliações: das políticas públicas, da figura da protagonista e da metacrítica, a crítica sobre a própria crítica.

Antes de tudo, no entanto, é preciso situar em que ambiente se desenvolve a elaboração cinematográfica no Brasil. A formação do cinema brasileiro, com uma base pouco consolidada de filme, produção e público, ainda se apresenta bastante deficitária, principalmente em razão da desvalorização do produto nacional evidenciada pela falta de investimentos - no orçamento e na divulgação $=$ e por uma série de preconceitos identitários quanto às figuras retratadas em cena, cristalizações disseminadas pela história cinematográfica. 
Noutras palavras, como evidencia Autran (2009), sua recepção está fortemente comprometida em razão das políticas públicas instáveis e do atravessamento profundo de fatores ideológicos, que refletem numericamente no valor arrecadado e na escassa disseminação, mantendo-os abaixo na crítica e nas cerimônias de premiação. Através da história do cinema nacional (NAGIB, 2002; GATTI, 2008), soma-se a esse fator uma imagem negativa dos filmes brasileiros: construiu-se um estereótipo que reduz a produção fílmica a sátiras, comédias em excesso e filmes pornográficos, e poucos diretores destacam-se no sentido revolucionário de unir narrativa à técnica, rompendo essa cristalização, como Nelson Pereira dos Santos e Glauber Rocha, do Cinema Novo; Hector Babenco e Fernando Meirelles, na virada do século XXI; e Karim Aïnouz e Kleber Mendonça Filho, nos últimos anos.

A consolidação efetiva de um cinema nacional, a partir desse cenário, encontra sua barreira na manutenção desse olhar de inferioridade, por parte do público e do desinteresse estatal, que conduz a outro obstáculo: o de democratização da arte. Nessa efervescência cinematográfica, surge o filme Marighella (2019), dirigido por Wagner Moura, baseado na biografia de Mário Magalhães sobre o político e guerrilheiro Carlos Marighella, previsto inicialmente para ser lançado em 20 de novembro de 2019, dia da Consciência Negra, meses após sua primeira aparição no Festival Internacional de Cinema de Berlim. A princípio, para possibilitar uma discussão mais produtiva, é necessário definir o que se chama "cinema" e qual/em que local o Brasil ocupa.

\section{O cinema e suas vicissitudes}

A história do cinema remonta, conforme Metz (1977), à Europa pós-Revolução Industrial, tendo como destaque os franceses Georges Meliès, Auguste e Louis Melière. A evolução ao contexto sociocultural da França, o berço da técnica, posteriormente avança a todo o continente, ao imperialismo estadunidense e ao domínio do mundo bipolarizado. O diálogo com as diversas artes complementou a associação fílmica entre experimentalismo e narrativa, fruição estética que percorre a função pragmática do cinema através do expressionismo alemão, do neorrealismo italiano, do yakuza japonês, do realismo socialista soviético e do cinema novo brasileiro, por exemplo. Esses movimentos, em particular o do Brasil, procuram engendrar uma produção técnica essencialmente identitária, suprindo os poucos recursos técnicos 
V. $11(1)$

1-19

jan-abr

2021

com uma linguagem criativa, voltada a narrativas críticas, distintas e autorais, que tratam a própria cultura.

O termo linguagem torna-se recorrente no desenvolvimento da teoria (ou teorias) cinematográfica. Pode-se definir que é por meio da linguagem que se define cinema e como essa arte é estabelecida através da história, conceito trabalhado pela teoria de Christian Metz, formulada a partir da crítica pós-estruturalista, ou seja, um diálogo entre as noções estruturais de sistema e os padrões de significação de uma possível hermenêutica interna:

o cinema, sem dúvida nenhuma, não é língua, contrariamente ao que muitos teóricos do cinema mudo afirmaram ou sugeriram, mas pode ser considerado como uma linguagem, na medida em que ordena elementos significativos no seio de combinações reguladas, diferentes daquelas praticadas pelos nossos idiomas (sic), e que tampouco decalcam os conjuntos perceptivos oferecidos pela realidade (esta última não conta estórias contínuas). A manipulação fílmica transforma num discurso o que poderia não ter sido senão o decalque visual da realidade. Partindo de uma significação puramente analógica e contínua - a fotografia animada, o cinematógrafo -, o cinema elaborou aos poucos, no decorrer de seu amadurecimento diacrônico, alguns elementos de uma semiótica própria, que ficam dispersos e fragmentários no meio das camadas amorfas da simples duplicação visual (METZ, 1977, p. 126).

A proposição realizada por Metz de uma "semiologia do cinema", que busca estabelecer padrões de significação à produção fílmica, considera o filme como materialização do verbal e do não verbal, das imagens em movimento, as quais adquirem e transmitem sentidos e experiências apenas na/pela estética da recepção. Noutras palavras, a partir de uma projeção semiótico-textual, os elementos sígnicos que permeiam a obra, manipulados pela fotografia, direção de arte, edição etc. e revestidos de conteúdos semânticos pelo diretor, só são efetivamente apreendidos pelo processo de percepção-significação por parte do público, da captação sensorial da recepção.

Este é um ponto-chave para compreender (ou, pelo menos, questionar) as razões pelas quais o cinema brasileiro não atinge o título de sistema bem consolidado. Por meio da semiologia de Metz, podese pensar que o esvaziamento semântico da produção nacional advém fundamentalmente de sua recepção, já que, pela falta de público, não há condições possíveis para a captação sensorial de modo legítimo, a partir da própria arte. Essa problemática pode ser percebida não só por causa da ausência de investimentos e da baixa quantidade de salas de cinema 
que exibem filmes brasileiros, como enumera Gatti (2008, p. 38), mas também por uma "noção antropológica". Nessa concepção, Droguett (2007, p. 8), ecoando Metz, considera a importância de uma identificação cinematográfica em que aspectos culturais são perceptíveis no imaginário cênico e é por meio desse reconhecimento que a liberação das energias sensoriais do público conduzem à "experiência estética, inseparável da vida social". A dicotomia 'pertencimento vs. não pertencimento' pode ser considerada, dessa maneira, como fator complementar à rejeição ao cinema nacional, uma vez que aponta ao apagamento generalizado da imagem/identidade representada nas telas.

Quando se discute sobre identidade nacional, incorre-se em outro aspecto essencial que interpela toda a produção cinematográfica no Brasil: as políticas públicas. Para suprir essa "falta" de representação social, procurando ampliar a difusão cultural e o acesso da população à arte, uma alternativa é direcionar ao Estado a responsabilidade, em alguma medida, de fomentar o audiovisual:

duas dimensões políticas ganham relevância no estímulo ao cumprimento desse objetivo: a universalização dos bens e serviços culturais ofertados a toda a população, através de equipamentos, programas e serviços públicos permanentes de cultura que incentivem a formação de hábitos de fruição cultural e promovam a visibilidade e a troca de produções culturais e artísticas locais e comunitárias, e a luta por uma educação de qualidade, pensada como via fundamental de crescimento pessoal e coletivo, promotora de autonomia, independência e identidade (PORTO, 2007, p. 170).

Por meio dessa concepção de política e de Estado, evidenciase um caso especial no cinema nacional. Marighella, filme dirigido por Wagner Moura, teve seu lançamento interrompido em 2019 por controvérsias envolvendo instituições governamentais. Inicialmente previsto para ser divulgado nas salas brasileiras a partir de 20 de novembro, simbolizando o dia da Consciência Negra e os cinquenta anos da morte do guerrilheiro retratado, a Agência Nacional do Cinema (Ancine), órgão vinculado à Secretaria da Cultura, impediu sua propagação sem manifestar justificativas específicas. Nesse momento, ecoa outro ponto importante a ser discutido: o cinema como palco de luta ideológica, uma espécie de ringue em que discursos antagônicos se chocam e manifestam linguisticamente valores de distintas ordens. 
V. $11(1)$

1-19

jan-abr

2021

\section{Pulsações ideológicas e o cinema como combate}

A definição de ideologia é discutida, questionada e polemizada por diversos campos de estudos, mas, em linhas gerais, compartilham a ideia de ser um conjunto de elementos socialmente naturalizados através da história e institucionalizados pela política. Assim como Metz, interessado pelo processo de significação, o Círculo de Bakhtin, composto por Mikhail Bakhtin, Valentín Volóchinov, Pavel Medvedev e outros estudiosos, questiona a articulação do signo a partir da filosofia da linguagem, bem como observa aspectos ideológicos e a interação verbal de sujeitos sócio-históricos. Bakhtin (2002; 2003; 2013a; 2013b) e Bakhtin/Volóchinov (2014), situados no contexto pós-Revolução Russa, teorizam linguisticamente com base na crítica literária que lhes fornece, a partir de Dostoiévski, Pushkin e outros, noções como polifonia, dialogismo, cronotopo, gênero e estilo ${ }^{1}$

A partir dessa epistemologia, o signo linguístico é apreendido em sua articulação semiótico-ideológica, isto é, o significante/ significado é mediado a partir de fatores socialmente construídos, que moldam seu sentido. O signo, portanto, está submetido à reflexão e à refração das posições sócio-ideológicas de uma realidade natural ou social. Uma espécie de consciência social rege a expressão do signo, que manifesta, em quaisquer ocasiões, a ideologia a qual o inscreve, o circunscreve e o atravessa na infra e superestrutura, conforme a teoria marxista da sociedade, bases das instituições sociais:

No domínio dos signos, isto é, na esfera ideológica, existem diferenças profundas, pois este domínio é, ao mesmo tempo, da representação, do símbolo religioso, da fórmula científica e da forma jurídica etc. Cada campo de criatividade ideológica tem seu próprio modo de orientação para a realidade e refrata a realidade à sua maneira. Cada campo dispõe de sua própria função no conjunto da vida social. É seu caráter semiótico que coloca todos os fenômenos ideológicos sob a mesma definição geral (BAKHTIN/VOLÓCHINOV, 2014, p. 33).

Essa teoria sígnica é expandida a partir de outros conceitos definidos a partir das múltiplas relações de sentido construídas na

\footnotetext{
${ }^{1}$ Os diversos ensaios e textos divulgados pelo Círculo de Bakhtin são desenvolvidos a partir da crítica literária produzida na então União Soviética, que se debruça sobre a literatura de Dostoiévski e a lírica de Pushkin, por exemplo. Além da repercussão e da recepção da(s) perspectiva(s) bakhtiniana(s) na teoria do romance, os conceitos apresentados também são apreendidos em pesquisas que se constroem em torno da teoria da enunciação e do discurso. Esta breve seção busca apenas situar alguns destes conceitos, em especial dialogismo, força centrípeta/centrífuga, reflexão/refração, os quais serão mais discutidos no momento de análise.
} 
materialização dos discursos. A partir da poética dostoievskiana, Bakhtin (2013) define o dialogismo como o entrelaçamento de vozes discursivas no momento da enunciação. A interação verbal, nesse sentido, pressupõe que o sujeito é construído historicamente, por múltiplas e heterogêneas vozes: as relações de sentido só se tornam possíveis com base em enunciados prévios, que não se resumem ao diálogo face a face, mas também a atitudes responsivas, pontos de vista ou juízos de valor. Sinteticamente, pode-se dizer que

o enunciado está repleto de ecos e lembranças de outros enunciados aos quais está vinculado [...] o enunciado deve ser considerado acima de tudo como uma resposta a enunciados anteriores: refuta-os, confirma-os, completa-os, baseiase neles. A inter-relação que se estabelece entre o discurso inserido do outro e o resto do discurso não tem analogia com as relações sintáticas existentes dentro dos limites de um conjunto sintático simples ou complexo [...] as fronteiras que essa alternância edifica são nesse caso tênues e específicas: a expressão [do enunciador] se infiltra através dessas fronteiras e se difunde no discurso do outro (BAKHTIN, 2003, p. 316).

Essa teoria preconiza, assim, que interdiscursos interrelacionam em intertextos, ou seja, no campo dos discursos - formados pela linguagem a partir da história - dialogam-se e materializamse textualmente. Conforme Bakhtin (2013a, p. 318), é impossível depreender o enunciado "sem relações lógicas e concreto-semânticas", aquelas que orientam a efetividade do texto a partir de discursos prévios e construindo novos discursos. Essa movimentação explicita a relação entre o dizer e a realidade biossocial que o circula, direcionando sua concretude.

Por fim, o pensamento bakhtiniano se complementa com base numa observação a qual traz os conceitos de força centrípeta e força centrífuga, que tracionam essas vozes discursivas. Em analogia à mecânica clássica, esses termos se relacionam tanto com a articulação semiótico-ideológica quanto com o dialogismo: segundo Bakhtin (2002, p. 82), a força centrípeta centraliza o discurso e, simultaneamente, a centrífuga o descentraliza e o desunifica a partir de uma orientação ideológica. Nesse olhar, há duas "forças" que envolvem o ato enunciativo e explicitam a dinamicidade da língua, capaz de manifestar a diversificada interação verbal e de se adequar às vozes que se entrechocam nas ideologias em jogo.

O entrelaçamento dessas vozes, modificadas e/ou intensificadas a partir de forças ideológicas, está em todas as ordens sociais e, na arte, 
V. $11(1)$

1-19

jan-abr

2021

essa articulação se repete. Sendo o cinema significado e ressignificado a partir de sua estrutura interna e externa, como retoma a teoria de Christian Metz, sua expressão sígnica está condicionada às formações discursivas que compõem os sujeitos envolvidos nesse processo de produção fílmica, em especial o diretor e o público. É nesse sentido que Marighella e suas (contra)dições, na emergência de seu lançamento, presenciam um embate que reflete e refrata sua própria realidade e ordena seu curso de recepção e avaliação.

\section{Marighella: reflexões e refrações}

A figura de Carlos Marighella, guerrilheiro opositor à ditadura militar no Brasil, já fora retratada em duas obras cinematográficas: o documentário Marighella - retrato falado do guerrilheiro (2001), de Silvio Tendler, e Batismo de sangue (2007), de Helvécio Ratton. Fundador da Ação Libertadora Nacional (ALN), Marighella foi um dos nomes de destaque na luta armada contra o regime militar, assassinado pelo governo em 4 de novembro de 1969, um ano após criar o grupo. Nas narrativas fílmicas prévias, Gutfreind e Stigger (2013, p. 55) concluem que "a representação da morte é um dos fatores que legitima a heroicização de Marighella", como um homem político, capaz de enfrentar as durezas de sua época, que sobreviveu a séries de tortura e "transcende sua morte o sujeito de si, [tornando-se] um ícone de resistência".

A representação do guerrilheiro retorna às telas de cinema em 2019 com a produção dirigida por Wagner Moura e baseada na biografia Marighella - o guerrilheiro que incendiou o mundo, escrita por Mário Magalhães. Prevista inicialmente para lançamento em 20 de novembro daquele ano, uma série de reações positivas e negativas emergiu nas redes sociais, trazendo valores ideológicos diversos, como se expressa principalmente na brasileira Filmow. A plataforma é destinada especificamente ao espaço de crítica e avaliação cinematográfica, como um índice de catalogação de filmes e comentários variados sobre as obras assistidas.

No momento de coleta de dados, em outubro de 2019, a página do filme na rede Filmow apresentava o seguinte cenário: nota média de 2,6/5,0, baseada em vinte e dois votos; 5317 usuários marcaram "Quero ver", enquanto 323, "Não quero ver", e os comentários contabilizaramse em 436. A publicação mais antiga foi realizada em 2013, e a maioria 
das discussões foi definida entre janeiro e abril de 2019 e após o cancelamento instituído pela Ancine em setembro do mesmo ano. Vale destacar, ainda, que a obra está situada em algumas listas do próprio site, como as intituladas "História do Brasil", "Descolonizar é possível?" e "Ditadura nunca mais!".

Dos 436 comentários, 72 foram excluídos ou bloqueados pelos moderadores da rede, o que indica $16,51 \%$ das reações. Dos restantes, $22(6,04 \%)$ reduzem-se a uma linha ou a uma palavra ofensiva, do tipo "Lixo" ou "Dá nojo de olhar". Também se evidenciam os comentários de metacrítica, isto é, que questionam a crítica não fundamentada de outros usuários, acusados de se posicionarem sem assistir à obra: 129, 35,44\% das publicações. Assim, tendo em vista esse cenário e considerando que diferentes conteúdos aparecem numa mesma resposta, os comentários mais avaliados e respondidos merecem atenção e espaço de análise maior.

Quadro 1 - Distribuição dos comentários de acordo com seu conteúdo

\begin{tabular}{|c|c|c|}
\hline Categorias & Comentários & Percentuais \\
\hline Comentários sobre políticas públicas & 13 & $3,57 \%$ \\
\hline Visão positiva de Carlos Marighella & 37 & $10,16 \%$ \\
\hline Visão negativa de Carlos Marighella & 115 & $31,59 \%$ \\
\hline Comentários-metacrítica & 129 & $35,44 \%$ \\
\hline
\end{tabular}
Fonte: Dados da pesquisa.

Antes desse olhar mais detalhado, vale ressaltar que esta pesquisa se desenvolve no espaço digital, onde o uso da linguagem depende do affordance, como adverte Vallada (2020), ou seja, do design da plataforma em que os perfis se encontram e interagem. A rede Filmow, por exemplo, cria o produtivo cenário de análise por se tratar de uma plataforma que funciona não só como base de dados de filmes, mas também proporciona a avaliação, os comentários, as respostas aos comentários, a criação de listas, de grupos, pedidos de amizade e troca de mensagens. Com isso, é importante ter em mente que transformações sociolinguísticas também exigem transformações metodológicas, "que considerem as complexidades das interações linguísticas pós-digitais" (VALLADA, 2020, p. 1166), que compreendam, como no caso de Marighella, a fusão entre online e offline, quando a produção cinematográfica reverbera nas/por meio das tecnologias digitais. 
V. 11 (1)

1-19

jan-abr

2021
O início do conflito: a negação da existência

Destaca-se, principalmente nas primeiras avaliações sobre Marighella, usuários que se posicionam contrariamente à obra com a alegação de uso indevido de recursos públicos. Assim, compartilham a ideia de que a existência do filme é invalidada já pela própria produção; no entanto, respostas a estes trazem uma visão oposta, como se observa a seguir.

Figura 1 - Comentários envolvendo políticas públicas
(A)
(1) 1 ano atrás
editado

Pesquisem a VERDADEIRA história desse terrorista. Leiam o Manual do Guerrilheiro Urbano que esse facínora escreveu. Apesar que é assim que os esquerdistas caviar que amam um capitalismo pensam hj em dia no Brasil: Se for pela revolução e pela causa esquerdista, vale tudo: Quer fazer um filme endeusando terrorista? Beleza! Mas não usem o nosso dinheiro!

(B) ๑ 1 ano atrás

10 milhões de dinheiro público pra fazer um filme de um terrorista. Aquele famoso ódio do bem, se matar branco de direita está perfeito!

(C) $\odot 1$ ano atrás

Eca. Dinheiro público sendo gasto para financiar um filmeco glorificando um terrorista? Tô fora. Vergonha alheia do cinema desse país.

(D) ๑ 1 ano atrás

Não é o filme de milícia, como o seu presidente ama e idólatra. Sai daqui nazista.

(E) $\odot 1$ ano atrás

Dinheiro investido em arte e dirigido por um dos maiores artistas da atualidade.

Cinema é arte, arte é necessário.

Teu comentário é super medíocre em vista que se fosse sobre um ídolo teu, seja lá quem for, você estaria aplaudindo com o cu. Se assistir e não gostar será sua crítica, mas vir sem nem ter visto é só achismo e besteira.

Fonte: Filmow.

Os cinco comentários selecionados na figura 1 lançam juízos de valor acerca da produção orçamentária do filme, sendo uma justificativa para que não deva ser difundido. Preconiza-se, portanto, a ideia de que o dinheiro público é utilizado em produtos de ideologias contrárias à parcela da sociedade e, como consequência, invalida sua existência. Essa rejeição ao cinema converge, como indica Gatti (2008), à não representação social da temática, isto é, surge uma aversão pelo pressuposto da obra: no caso de Marighella, os comentários (A), (B) e (C) divulgam a imagem do guerrilheiro como um "terrorista", e o filme subverte a "verdadeira história", por meio de um olhar "de esquerda", em que a protagonista é "glorificada", construção feita a partir do "dinheiro"/políticas públicas financiadas para sua realização. 
Aqui, percebe-se um atravessamento do discurso político e histórico, organizado a partir de vozes prévias que compartilham a visão terrorista de Carlos Marighella. A partir do pensamento bakhtiniano, "a multiplicidade de vozes, consciências independentes e imiscíveis e a autêntica polifonia de vozes plenivalentes" (BAKHTIN, 2013a, p. 4) contornam a história armada do guerrilheiro, fortemente contrariada, e a mediação política do financiamento à produção de um filme que não representa os seguidores dessas vozes circundantes gera enfrentamentos. Elas se constituem de uma voz política que polariza "esquerdistas caviar" (A) e "branco de direita" (B) e de uma voz histórica que permite classificar Marighella como "terrorista", adjetivação selecionada pelos três comentários, explicitados, em (A), pelo imperativo em tom injuntivo, direcionando os demais usuários à "verdade" histórica defendida, e pela coletividade desse pensamento político, com o possessivo "nosso"; em (B), pela topicalização do suposto valor aplicado - "10 milhões [de reais]" - e, em (C), pela aversão expressa no uso interjetivo, como "Eca" e "Tô fora".

O diálogo direto, biunívoco, representado por (D) e (E), como respostas a (C), indica outra construção discursiva: a de que o "investimento" é necessário para disseminação da arte. Ambas atitudes responsivas, segundo as ideias bakhtinianas, revelam uma ordenação das forças centrípeta e centrífuga, que tracionam a produção dos signos, evidenciadas pela figura de "ídolo": (D) insere a oposição "milícia" vs. "guerrilheiro" e associa o termo "nazista" ao primeiro, enquanto (E) deslegitima a fala de (C) ao dizer que a crítica exposta é baseada na visão ideológica da imagem representada, sem tê-lo assistido.

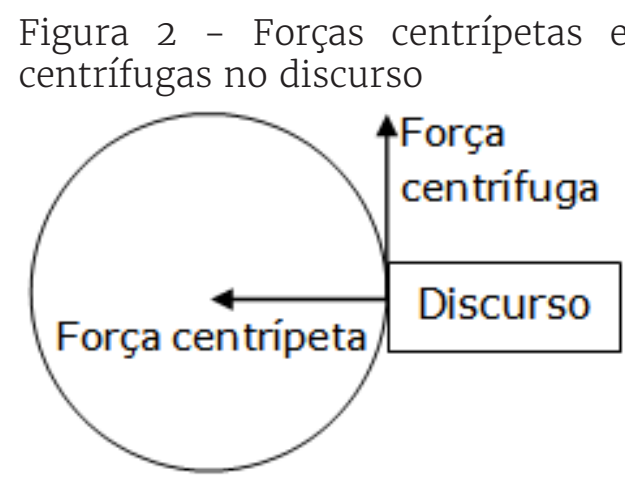

Fonte: Elaborado pelo autor com base em Bakhtin (2002).

Como indica a analogia expressa na figura 2, relacionando o movimento curvilíneo da mecânica clássica à tensão dos discursos 
V. 11 (1)

1-19

jan-abr

2021

definida por Bakhtin (2002), é possível depreender que há forças as quais agem sobre o discurso e, em seguida, refletem e refratam sua realidade. Esse espaço é resultado do movimento dialógico que traz, como exposto na figura 1, sujeitos sócio-históricos capazes de se posicionarem favorável ou contrariamente à obra, uma vez que

ao lado das forças centrípetas caminha o trabalho contínuo das forças centrífugas [e], ao lado da centralização verboideológica e da união caminham ininterruptos os processos da descentralização e desunificação. (BAKHTIN, 2002, p. 82).

A legitimidade da produção é, portanto, questionada a partir do investimento público - força centrípeta, centralizadora, comum à crítica dos usuários - , mas validada ou invalidada a partir das forças centrífugas, que promovem uma diferenciação nessa avaliação em torno da imagem do guerrilheiro, diversificada também em outros comentários.

\section{Desdobramentos críticos e metacríticos}

O embate entre os usuários, todavia, não permanece apenas na discussão acerca dos recursos públicos: a figura da protagonista é questionada e caracterizada de forma bem diversa, ora positiva, ora negativamente. Nesse cenário, outros usuários interrogam se esse aspecto é relevante para a crítica cinematográfica da obra de Moura.

Figura 3 - Comentários positivos sobre a imagem de Carlos Marighella (F) $\odot 1$ ano atrás

"guerrilheiro: um cara que lutou, com as armas que dispunha, para libertar o país de uma ditadura militar sangrenta

torturador: um cara que usava de sua posição para praticar sadismo com seres humanos em nome de uma ditadura militar sangrenta

escolha o seu lado. eu já tenho o meu"

(G)

(1) 7 anos atrás

No aguardo para ver um dos maiores heróis da história do Brasil!!!

( $\mathrm{H})$

(1) 6 anos atrás

Mal, posso esperar pelo filme.Li o livro, gostei bastante, não conhecia a história desse herói, e fiquei simplesmente encantada. Acredito que esse filme sirva para divulgar a história desse homem pouco conhecida no Brasil, e que de certa forma demonstra o que é o povo brasileiro. Confio, que o Wagner Moura não vá me decepcionar, um grande ator, que tem tudo para ser um grande diretor

\section{(I) $\bigcirc 2$ anos atrás}

Herói foi Santos Dumont, que inventou o avião e melhorou a vida de todos nós. Marighella foi só um guerrilheiro que quis desbancar uma ditadura e substituí-la por outra ainda pior.

Preguiça de pensar define a geração Che Guevara e Bolsonaro.

Fonte: Filmow. 
Alguns comentários realizados na rede exaltam Carlos Marighella a partir da oposição acima descrita, considerando-o como herói e importante combatente do regime militar nos primeiros anos. Assim, (F), (G) e (H) revelam o desejo com o lançamento da obra, pois a representação social converge com a visão ideológica expressa: "[o guerrilheiro] lutou [...] para libertar o país de uma ditadura militar sangrenta", e a divulgação de sua história como "herói", tal qual retratada pela biografia que lhe serve de base, é relevante para o cinema brasileiro. A atitude responsiva de (I), no entanto, refrata a realidade construída por $(\mathrm{H})$, uma vez que ressignifica o termo utilizado com outra figura: situar Santos Dumont em oposição a Carlos Marighella, nesse sentido, além de promover uma interação dialógica direta, expressa valores opostos, já que herói se redireciona àqueles que lutaram por "melhor[ar] a vida" e não se reduz a situações políticas, como o objetivo do guerrilheiro de "desbancar uma ditadura".

Figura 4 - Comentários negativos sobre a imagem de Carlos Marighella

(J) $\quad 1$ ano atrás

Se o filme for bom como ficção( boa direção, fotografia, roteiro), vou dar uma boa nota pela ficção.

Mas pelo que já li ( inclusive o Manual do Guerrilheiro Urbano), considero Marighella um terrorista sim, inclusive consigo enxergar a intenção do Wagner Moura com esse filme, mas não vou entrar nesse mérito.

Ignorando toda essa discussão política aqui no filmow, só quero dizer que vou julgar o filme pelo filme, como obra ficcional com total suspensão de descrença como faço quando assisto filmes sem relação imediata com a realidade ( que ao menos pelas entrevistas do Wagner Moura, parece ser o caso).

(K) $\odot 1$ ano atrás

Filme político, revisionista e enaltecedor de um extremista de esquerda. Tem que apedrejar até o fim sim

(L) $\bigcirc 1$ ano atrás

Espero que tenha filmado lindamente o Marighella sendo fuzilado.

(M) $\quad$ (1) 1 ano atrás

Ansioso para ver a cena que transformam o Marighella numa peneira.

(N) $\odot 1$ ano atrás

Canalhas fazendo filme sobre um canalha. Nada de novo.

Fonte: Filmow.

A quantidade de comentários negativos acerca de Carlos Marighella e do próprio filme são suficientemente maiores que os declaradamente positivos. Ao contrário destes, assume-se como premissa a imagem terrorista do guerrilheiro, e o filme serviria apenas 
V. $11(1)$

1-19

jan-abr

2021

para deturpar a manutenção desse pensamento. A (inter)subjetividade, na noção bakhtiniana, se constrói no discurso de outrem, na historicidade, e os comentários expressos por $(\mathrm{K})$ e $(\mathrm{N})$ trazem essa consideração histórica de que o filme é uma espécie de propaganda política que deve ser "apedreja[da]". A fala de (J), por sua vez, isola a crítica cinematográfica dessa discussão, devendo ser avaliada apenas na/pela "ficção", isto é, o "filme pelo filme", mas deixa claro seu posicionamento diante de Marighella e explicita os valores conflitantes em sua divulgação, sobretudo na escolha de Wagner Moura na organização fílmica.

Os comentários de (L) e (M) concentram-se no assassinato do guerrilheiro, mas não no sentido transcendental e metafísico exposto por Gutfreind e Stigger (2013), e sim na brutalidade e no extermínio, considerando a eliminação do opositor. Ao expressarem o desejo cinematográfico da exibição cênica do "fuzilamento", a escolha lexical reposiciona Marighella em posição sufocada na luta armada, remanejamento que, segundo Bakhtin (2013a), traça um confronto de interesses sociais e um jogo de sistema de valores, resultado da historicidade e das múltiplas verdades. Considerar o guerrilheiro "extremista", portanto, não advém de uma ideia monodialógica, mas de discursos prévios e atravessados, como a ditadura militar, governos posteriores, obras literárias, notícias, testemunhos etc.

Esses dois comentários podem ser analisados também a partir da estética da recepção de Metz (1977), uma vez que revelam o modo como a experiência sensorial deve ser apreendida através da ordenação cinematográfica. O filme, segundo essa concepção, conseguirá avaliação e crítica positivas apenas se dispuser dos recursos cênicos para retratar o assassinato do guerrilheiro de forma violenta e sádica. A elaboração fílmica proposta por esses usuários indica que a sensação eufórica, termo da semiologia do cinema para designar fruição estética, está condicionada à captação visual do fuzilamento, experiência catártica.

Esses exemplos tornam explícito o modo de recepção do cinema nacional descrito anteriormente: apesar de não ter sido lançada, a obra apresenta diversas reações críticas que ignoram aspectos essencialmente cinematográficos, como roteiro, mixagem de som, direção de arte, fotografia etc. e evidenciam uma aversão político-ideológica às imagens retratadas nas telas. Assim, os comentários trazidos pelas figura 1 e figura 4 dividemse em especular quais cenas deveriam ser expostas, como o assassinato de Marighella de forma brutal, e em depreciar o filme por duas vias: a colocação do uso de dinheiro público e a propaganda política por trás da narrativa. 
Figura 5 - Comentários metacrítica

(O) $\bigcirc 1$ ano atrás

O cara era um italiano branco, e colocaram um ator negro pra interpretá-lo. O cara era um terrorista assassino, e foi colocado como herói

LIXO

(P) 11 ano atrás

Vc viu o filme?

(O) $\bigcirc 1$ ano atrás

E precisa?

(Q) $\bigcirc 1$ ano atrás editado

Marighella foi um grande revolucionário.

Criticar o filme (antes da estréia) só por ser lambedor de bota de milico é de um mau caratismo sem tamanho

Fonte: Filmow.

A maior parte dos comentários expressos na rede brasileira focalizou-se numa metacrítica, ou seja, em críticas que debatem outras críticas; no caso exposto, diversos usuários manifestaram-se contrários à avaliação prévia de outros. O diálogo entre $(\mathrm{O})$ e $(\mathrm{P})$ resume a reflexão realizada no Filmow: $(\mathrm{O})$ revela não querer assistir à obra e a classifica como "lixo" por retratar um "terrorista assassino" de forma subvertida, o que a deslegitima também por representar um "italiano branco" na imagem de um "ator negro"; (P) questiona diretamente se ele já havia visto a obra, e o usuário lhe responde com "E precisa?", supondo que não é necessário para realizar aquele comentário. A fala de (Q) complementa esse embate metacrítico por trazer como indignação "mau caratismo sem tamanho" - a ação de "criticar o filme antes da estreia". Ainda, traz a imagem positiva do guerrilheiro como "grande revolucionário" e direciona esse exercício crítico não fundamentado àqueles que reverberam o discurso de que Marighella é terrorista e procuram invalidar o filme de Moura antes do lançamento.

Esse aspecto discutido contraria a ideia central da significação cinematográfica trazida pela semiologia do cinema, uma vez que o público não passou pelo processo de percepção na geração de sentido (METZ, 1977, p. 76). Considerando o filme como produto semióticotextual, ou seja, objeto de significação materializado em imagens em movimento, as críticas direcionadas à obra especificamente, classificando-a positiva ou negativamente, não são respaldadas, pois a captação sensorial não se sustenta dissociada da apreensão das formas, manipuladas cinematograficamente, possível apenas no contato com o filme em si. 
V. $11(1)$

1-19

jan-abr

2021

As refrações encontram-se: uma síntese

Segundo Bakhtin (2002), a língua está submetida à homogeneização das ideologias verbais - força centrípeta mas também à heterogeneidade e ao plurilinguismo social - força centrífuga. Essas forças agem sob a atividade discursiva, de forma a modificar e a moldar o sentido da enunciação. Quando se diz, portanto, que Marighella é herói ou terrorista, tem-se uma união de ideologias contrárias em diálogo, que se dispersam a partir da formação subjetiva de cada enunciador. Essa formação também está resignada à perspectiva dialógica, uma vez que a subjetividade é construída na/ pela interação, erguida por discursos os quais atravessam o indivíduo desde seu nascimento e o faz refletir e refratar a realidade à sua volta. Os usuários das redes, como exposto, são sujeitos imersos num palco, a sociedade, em que discursos antagônicos se entrelaçam, constituem sua subjetividade e o fazem avaliar algum objeto de acordo com essa formação descentralizadora e, em seguida, refratária da realidade.

Figura 6 - Reflexão e refração em Marighella

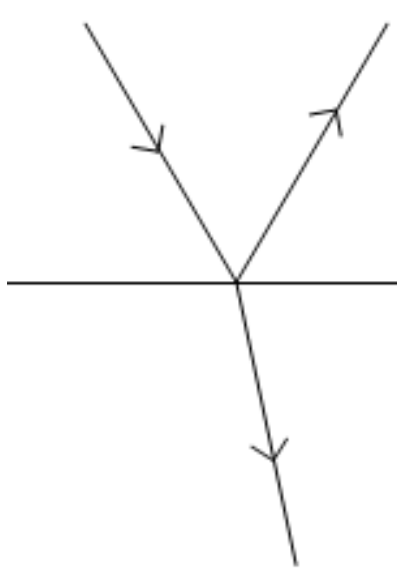

Reflexão:

(1) o próprio filme;

(2) Manual do guerrilheiro urbano;

(3) cancelamento pela Ancine;

(4) assassinato de Marighella pelo governo.

Refração:

(1) dicotomia: herói vs. terrorista;

(2) políticas públicas;

(3) revisitações históricas;

(4) rejeição ao cinema nacional.

Fonte: Elaborado pelo autor com base em Bakhtin/Volóchinov (2014).

Conforme ilustrado pela analogia da figura 6, por meio da linguagem, isto é, pelo ato enunciativo de dispor os discursos na materialidade textual, a obra Marighella constrói seu próprio sentido antes mesmo de sua distribuição nacional. Por "as formas do signo [serem] condicionadas tanto pela organização social de tais indivíduos como pelas condições em que a interação acontece" (BAKHTIN/VOLÓCHINOV, 2014, p. 44), os sujeitos manifestam nas redes sociais uma série de dizeres organizados a partir da própria formação discursiva, atravessada por vozes sócio-históricas e político-ideológicas, que se posicionam 
diante da realidade refletida e a refrata de acordo com esses valores. Àqueles que consideram Marighella herói e demonstram entusiasmo com a produção, percebe-se a exaltação do caráter revolucionário e da função disseminadora de sua história por meio da narrativa fílmica; àqueles que o consideram terrorista, ecoa forte aversão à elaboração cinematográfica, com ataques de diferentes naturezas às políticas públicas, à figura do guerrilheiro e à do diretor Wagner Moura.

Pode-se depreender, por meio da ilustração expressa na figura 6, baseada no fenômeno óptico-ondulatório, que, exterior à estrutura do filme, tem-se como elemento o qual reflete a realidade o Manual do guerrilheiro urbano (1969), do próprio Carlos Marighella, refratado por alguns usuários que o caracterizam como registro de ações terroristas. $\mathrm{O}$ cancelamento pela Ancine, embora não justificado pelo órgão, também possibilita pensar a refração em torno das políticas públicas: a aplicação no setor cinematográfico é vista ora como financiamento indevido para glorificação de um terrorista, ora como investimento relevante para a arte brasileira. Por fim, outro aspecto descentralizado é o assassinato de Marighella pelo governo ditatorial: esse evento é visto tanto como atitude sádica de um regime sangrento, como execução legítima de um opositor.

Esse cenário conflitante, unido à estética da recepção, está situado no momento sensorial de percepção de sua própria produção, o qual gera reações de ordens distintas, ora contrárias, ora favoráveis. No entanto, traçar uma relação biunívoca entre obra e representação social ignora a recepção do filme efetivamente em sua idealização - a de gerar sentidos no momento da contemplação da obra em si -, o que intensifica, em alguma medida, a aversão ao cinema nacional e impossibilita a plena disseminação da arte no Brasil.

\section{Considerações finais}

Por meio da dimensão dialógica e ideológica da linguagem, a capacidade do signo refletir e refratar uma realidade manifesta-se nas reações diversas presentes nos comentários publicados em rede. O antagonismo entre a figura de Carlos Marighella, ora herói, ora terrorista, é o centro da discussão midiática e esclarece as razões por trás dos obstáculos em seu lançamento. A questão da representação social, ordenada pelas políticas públicas e pelas forças ideológicas manifestas em distintas ordens estruturais, refletem e refratam a realidade da obra 
V. $11(1)$

1-19

jan-abr

2021

dirigida por Wagner Moura, principalmente por moldar os interesses externos e as discussões que retomam à época do regime militar.

Pela interação no espaço digital, em especial na rede Filmow, a partir da teoria de Bakhtin (2002; 2003; 2013a; 2013b) e Bakhtin/ Volóchinov (2014), torna-se possível argumentar que vozes de diferentes campos sócio-históricos são evocadas nas discussões em torno de Marighella, em específico, e do cinema brasileiro, em geral, e são elas as responsáveis por orientar o sentido da enunciação e modificar ou manter o olhar inferiorizado à produção nacional, por exemplo. O cerne dessa modificação, como exposto pela estética da recepção, construída pela semiologia do cinema de Metz (1977), está no reposicionamento do macroestrutural, isto é, do público, única via de experimentação sensorial do filme brasileiro, que exige (ou não) políticas públicas concernentes à sua distribuição e, por conseguinte, à democratização da arte no país.

Agradecimentos: Agradeço à supervisão do Prof. Dr. Rubens DamascenoMorais (UFG), às conversas em/na rede com Arthur Leite e à avaliação dos(as) pareceristas deste texto.

\section{Referências}

AUTRAN, Arthur. O cinema brasileiro contemporâneo diante do público e do mercado exibidor. Significação, São Paulo, v. 36, p. 119-135, 2009.

BAKHTIN, Mikhail. Problemas da poética de Dostoiévski. Rio de Janeiro: Forense Universitária, $2013 a$.

BAKHTIN, Mikhail. Questões de estilística no ensino de línguas. São Paulo: Editora 34, 2013b.

BAKHTIN, Mikhail. Estética da criação verbal. São Paulo: Martins Fontes, 2003.

BAKHTIN, Mikhail. Questões de literatura e de estética: a teoria do romance. São Paulo: Hucitec Editora, 2002.

BAKHTIN, Mikhail/VOLÓCHINOV, Valentín. Marxismo e filosofia da linguagem. São Paulo: Hucitec Editora, 2014.

DROGUETT, Juan. Estética da recepção cinematográfica: sobre os efeitos receptivos da produção midiática. Comunicação e Inovação, São Caetano do Sul, v. 8, p. 2-10, 2007.

GATTI, André Piero. A exibição cinematográfica: ontem, hoje e amanhã. São Paulo: Centro Cultural São Paulo, 2008. 
GUTFREIND, Cristiane; STIGGER, Helena. A resistência armada: Lamarca e Marighella no cinema nacional. Logos, Rio de Janeiro, v. 20, p. 48-60, 2013.

MARIGHELLA. Direção: Wagner Moura. Brasil: O2 Filmes, 2019.

METZ, Christian. A significação no cinema. São Paulo: Perspectiva, 1977.

PORTO, Marta. Cultura para a política cultural. In: RUBIM, A.; BARBALHO, A. (orgs.). Políticas culturais no Brasil. Salvador: Editora da UFBA, 2007.

NAGIB, Lúcia. 0 cinema da retomada: depoimentos de 90 cineastas dos anos 90. São Paulo: Editora 34, 2002.

VALLADA, Amanda Diniz. Digitalização e a luta pela linguagem. Trabalhos em Linguística Aplicada, Campinas, v. 59, n. 2, p. 1158-1170, 2020. 